\title{
Corrective Justice, Freedom of Contract, and the European Contract Law ${ }^{1}$
}

\author{
Szymon Osmola \\ European University Institute, Florence, Italy \\ szymon.osmola@eui.eu \\ Received 14 August 2018; accepted 13 January 2019; published 30 June 2019.
}

\begin{abstract}
Freedom of contract and corrective justice are considered to be the basic principles governing contract law. However, many contemporary legal orders implement various policy goals into private law. The regulatory private law of the European Union is the most striking example of such a trend. This article aims at reconciling the corrective justice theory of private law and the principle of freedom of contract with the regulatory dimension of the EU law. The main argument is that the meaning of the concept of harm, one that is crucial to the principle of corrective justice, should be understood broadly so that it can transform the corrective justice theory from a monistic one into a pluralistic one.
\end{abstract}

Keywords: corrective justice; freedom of contract; contract law; European Union law.

\section{Introduction}

There is no doubt about the fact that freedom of contract is one of the most important economic freedoms one can enjoy. It is especially important in contemporary market-oriented societies, where economic and political freedoms are often closely interconnected. Therefore, it does not come as a surprise that freedom of contract is crucially important for many of the leading contract law theories, especially those which embrace the value of personal autonomy.

However, it has recently been claimed, most notably by Martijn Hesselink, that most of the existing contract law theories - developed, despite their claims to universality, against

\footnotetext{
${ }^{1}$ The research on the contents of this article has been funded by the National Science Centre, Poland (grant no. 2017/27/N/HS5/01156). I would like to thank the anonymous reviewer for many valuable suggestions with regard to the previous version of the article.
} 
the background of the common law - do not consort with the European Union (EU) contract law (Hesselink, 2015). This is particularly true in case of monist contract law theories, which aim to ground contract law on a single fundamental principle, such as the principle of personal autonomy. According to Hesselink, those theories - he mentions theories based on the promise principle, consent, collaboration, or corrective justice (Hesselink, 2015 , p. 5) - are not able to grasp the specificity of the contemporary, highly regulated EU contract law. Therefore, as the author concludes, either (i) the EU contract law must be abandoned or radically reformed as inconsistent with leading theories; or (ii) the EU contract law must be considered as something totally different from the contract law that these theories are devoted to; or (iii) the leading theories of contract law must be deemed deficient in consistency with the EU contract law (Hesselink, 2015, pp. 14-18).

In general, I agree with Hesselink's remarks. However, I believe that at least some of the autonomy theories of contract law can be improved so that they can consort with the EU contract law. Therefore, in this article I will outline the way it might be done. I will focus on corrective justice theory, since I think it is the most promising one. The article is organized in the following way. In its first part, I will briefly introduce the corrective justice theory of contract law in its two forms, i.e. the strong one and the moderate one. I will also demonstrate the mutual relationship between the principles of corrective justice and freedom of contract. In the second part, I will outline the most characteristic features of the EU contract law, showing why they can be deemed inconsistent with the corrective justice theory and the principle of freedom of contract. In the third part, I will show how the corrective justice theory might be modified so that it can consort with the EU contract law. In short, I will argue that the meaning of the concept of harm, one that is crucial to the principle of corrective justice, should be extended in order to encompass different kinds of harms addressed by the EU contract law. This will also mean the transformation of the corrective justice theory from a monistic one into a pluralistic one. Finally, in the last part, I will try to put my considerations into a broader context of political theory, arguing that - transformed in the said way-the corrective justice theory can still be considered as liberal.

\section{2.}

For the purposes of this article, corrective justice may be characterized as the principle that requires repairing (correcting) harm wrongfully suffered by an individual. The harm in question may be a result of a tort, a breach of contract, or an unjust enrichment; in all of these cases an individual suffers the harm 'wronged' by another individual. Usually, it is also claimed that the harm should be repaired by (or, at least, on behalf of) the very same person that had committed the wrong. The exact way in which it is to be done is the question of the institutional architecture of a legal system (a matter irrelevant to the purposes here). As a matter of fact, my main argument would hold even if one concludes that the harm does not have to be repaired by (or even on behalf of) the same person who had committed the wrong. 
As mentioned before, there are two forms of the corrective justice theory of contract law, i.e. the strong one and the moderate one. According to the strong corrective justice theory, corrective justice should be the only principle governing contract law (and private law in general). The main representative of such an approach is Ernest Weinrib, who claims that:

Corrective justice brings together the aspects of unity, class, and character in a single approach to legal intelligibility. It is because the correlative gain and loss represent a distinctive unity that the structure of corrective justice differs from that of distributive justice. Conversely, the categorical difference between corrective and distributive justice means that the introduction of distributive considerations into corrective justice not only blurs separate categories but brings incoherence to the plaintiff-defendant relationship. Moreover, open-ended distributive considerations are incompatible with the bipolar link between the parties that characterizes the doctrines and institutions of private law. Thus under corrective justice, unity, kind, and character are the mutually reinforcing aspects of a formal understanding of private law. (Weinrib, 2012a, p. 76)

Even though Weinrib draws his conclusions primarily on the basis of tort law, he explicitly states that his theory is also applicable to contract law (cf. Weinrib, 2012b, p. 2). Moreover, although he writes about a categorical difference between corrective and distributive justice, he claims that all considerations that are different from those of corrective justice- be it moralistic, paternalistic, or economic - are inconsistent with the basic structure of private law. As a matter of fact, Weinrib seems to use these two terms, i.e. corrective justice and private law, interchangeably. The basic structure of private law consists of its essential features that are present in all its institutions, doctrines, and concepts (character), its kind, which constitutes its distinctiveness from different social phenomena, and its internal coherence that allows to frame it into one philosophical system (unity). Weinrib's conception of corrective justice is relational; the essence of corrective justice is supposed to be about the relationship between two subjects, reflected in the procedural relationship between a plaintiff and a defendant, who are the doer and the sufferer of the same injustice (be it tort, unjust enrichment, or a breach of contract). The value of corrective justice, i.e. the justification of private law, lies in the fact that it restores the parties' correlative standing to the state before injustice was done (e.g. in case of a breach of contract). What is crucial here is the 'bipolar link between the parties', making corrective justice a kind of 'private' justice between two persons, inconsistent with the open-ended considerations of distributive justice or any other kind of considerations.

The moderate corrective justice theory, on the other hand, claims that corrective justicenot necessarily understood in the metaphysical Weinribian way - is only one, though important, of the principles governing private and contract law. There is a variety of authors favoring the moderate theory in one form or another. I will limit myself to introducing two examples. The first one comes from John Gardner, who claims that although corrective justice, introduced by him in the form of the "continuity thesis" (cf. Gardner, 2011), is a crucial principle of private law, it is only the first step in establishing the correct functioning of a legal system. However, as it is virtually impossible to correct all harms wrongfully suffered by the subjects of the legal system, it must be followed by a second step, which is 
a proper (just) distribution of access to correction of the harms suffered (cf. Gardner, 2014). Those are distributive considerations that the strong theory explicitly rejects as part of the private law system. The second example comes from Hanoch Dagan, who claims that individuals' holdings that are subject to the principle of corrective justice have to be determined by some other principle beforehand. That principle is, generally speaking, distributive justice and, hence, it is possible to talk about the "distributive foundation of corrective justice" (cf. Dagan, 1999). Although Gardner's and Dagan's views are different (for the former one, the principle of corrective justice is logically prior to the principle of distributive justice, while for the latter one the opposite is true), both of them appreciate the role of distributive considerations in private law. Moreover, it seems that the proponents of the moderate corrective justice theory could also include reasons different from distributive considerations (e.g. economic or moralistic ones) in their account of private law. ${ }^{2}$

Corrective justice theory, both in its strong form and in the moderate dimension, is an autonomy-based theory of contract law. Either in Kantian conception of autonomy recognized by the proponents of the strong theory (cf. Weinrib, 2012a, pp. 9-37), or in the broader conception of autonomy as self-authorship, which is recognized by the proponents of the weak theory (Dagan and Heller, 2017, pp. 41-48), commitment to individual freedom, be it negative or positive, is evident. This is also true with regard to freedom of contract, which is one of the most important forms of expression of personal autonomy (cf. Kimel, 2001). The principle of corrective justice and the principle of freedom of contract mutually reinforce each other. The principle of corrective justice, a kind of 'private' justice between the parties of a contract, entails that the state (or any other entity) should not interfere with their will and the only permissible intervention should be to enforce, in case of a breach, the contractual obligations already agreed upon by the parties. Any further intervention in contractual terms would undermine the principles of freedom of contract and corrective justice. Therefore, according to the strong corrective justice theory, such interventions are either not permissible at all or, if permissible, they are outside of the domain of contract law; they are something different (e.g. public law). According to the moderate corrective justice theory, such interventions may be permissible in some cases, and it is indeed inevitable, but it does not change the fact that they compromise the principles of corrective justice and freedom of contract.

\footnotetext{
${ }^{2}$ I would argue that Aristotle himself was a proponent of the moderate corrective justice theory of private law. This can be seen in the passage from Nicomachean Ethics, one that has been frequently analyzed at least since the times of scholastics (cf. England, 2009, pp. 16-25): "For in many cases Reciprocity is at variance with Justice: for example, if an officer strikes a man, it is wrong for the man to strike him back: and if a man strikes an officer, it is not enough for the officer to strike him, but he ought to be punished as well".

The basic question is: why is the punishment more severe for a person who hits a prince than for the one who hits an ordinary person? The harm suffered by the prince is the same that the harm suffered by an ordinary citizen. Therefore, the harms to be compensated by the wrongdoer are equal. Therefore, how is it possible to justify the fact that the law punishes the same deed more severely only according to a social status of a victim? As the example itself — and the subsequent discussion — suggests, the answer is that there are different values, such as e.g. social hierarchy, that can govern a particular private law system alongside the principle of corrective justice.
} 
This last issue, namely various infringements of corrective justice and freedom of contract, is one of the reasons why some scholars are sceptical as to whether it is possible to apply (monist) contract law theories to contract law in the form in which they are emerging within the European Union.

\section{3.}

The European Union private law (and, therefore, also contract law) seems to be very different from traditional private law that is the point of focus for autonomy theories mentioned in the introduction, including corrective justice theory. It may be characterized by eight distinctive features that are closely connected to one another, namely: regulatory, instrumental, fragmented, and experimental character; privatization; anti-discrimination as the governing principle; the high level of consumer protection; and access justice. While there certainly are some more features of the EU private law that would be worth mentioning, as well as different classifications are possible (cf. Hesselink, 2015, pp. 8-13), the above-mentioned traits are the most important ones for our present purposes. I shall now briefly elaborate on each of them.

The regulatory character of the EU private law is best expressed through the title of Hans Micklitz's foundational paper, i.e. The Visible Hand of European Regulatory Private Law: The Transformation of European Private Law from Autonomy to Functionalism in Competition and Regulation (Micklitz, 2009). The EU private law departs from the traditional understanding of contract law as guided by the principle of freedom of contract for the sake of implementing a wide range of policy goals (cf. Comparato, 2016). Some of these above-mentioned goals, such as anti-discrimination, consumer protection, or access justice, are of such a great importance that they should be considered as stand-alone features of the EU private law. In terms of contract law, the regulatory character of the European law means lowering the level of discretion of contractual parties and, therefore, their freedom of contracting and introducing a variety of mandatory rules for different types of contracts. This trend is particularly visible in consumer law (see below). In general, all of the subsequent features of the EU contract law can be considered as more detailed expressions of its regulatory character.

Although the European Regulatory Private Law (ERPL) is designed to implement different policy goals, there is no doubt that its main aim-expressed for the first time in the 1985 White Paper on the Completion of the Internal Market (COM (1985) 310 final) - is to facilitate the EU Internal Market. The EU private law is economized and market-biased (cf. Micklitz, 2009, pp. 9-20). The anti-discrimination and consumer protection measures adopted by the EU, although inherently valuable, are subordinated to the crucial objective of "increasing industrial efficiency and competitiveness, leading to greater wealth and job creation" (White Paper, p. 18). Thus, the ERPL should be considered as predominantly instrumental, although there is also another possible interpretation, according to which the EU private law_despite its market-bias - genuinely promotes substantive values, such as 
anti-discrimination or substantive equality of contractual parties (cf. Dagan, 2016). It is worth noticing that if the merely instrumental interpretation is correct, there seems to be no point in considering the EU contract law in terms of corrective justice, since justice should never be regarded as an instrumental value. ${ }^{3}$

The European private law is fragmented, scattered, or sector-specific. This means that there are no general rules or principles governing the European contract law. The project of the European Civil Code (preceded by the so-called Draft Common Frame of Reference) has failed with regard to incorporating such general principles into a single legal act. Instead, as Hesselink writes, "The EU law is sector specific, addressing specific problems is specific sectors of the Internal Market, such as commercial agency, timeshare, package travel, late payment in commercial transactions, and consumer credit" (Hesselink, 2015, p. 8). The other examples involve: Union directives concerning the safeguarding of employees' rights in the event of transfers of undertakings, businesses or parts of undertakings or businesses (Directive 2001/23/EC); the general product safety (Directive 2001/95/EC); or the enforcement of intellectual property rights (Directive 2004/48/EC). All of this does not favor the monistic corrective justice theory, which tries to adopt the same measure of repairing harm to all types of contracts.

The experimental character and the privatization of the EU law are two sides of the same coin. In the globalized world, to role of the state in law-making and law-enforcing is visibly decreasing, while, on the other hand "an increasing number of non-state institutionsNGOs, multinational corporations, and individuals are relevant international or transnational actors" (Michaels \& Jansen, 2006, p. 868). The EU, with the process of law-making being highly influenced by various research groups, private consultancy firms, or stakeholders, is the most glaring example of such a phenomenon (cf. Micklitz, 2009, pp. 3640). The multi-level structure of the European law-making and law-enforcing contributes to highly experimental character of the European law, as it is virtually impossible to predict how different actors (including state and European courts) will structure their interactions (cf. Micklitz, 2017). The experimental character of the EU law amounts to a high degree of uncertainty among legal actors, whereas the privatization obviously creates room for excesses. Therefore, both of these features seem to be at odds with the principle of corrective justice (and with the rule of law in general).

Anti-discrimination. At the very beginning, anti-discrimination principles were supposed to regulate only the European labour law. However, over time and with adopting many directives (e.g. the Directive 2000/43/EC that implemented the principle of equal treatment between persons irrespective of their racial or ethnic origin, or the Directive 2004/113/EC that implemented the principle of equal treatment between men and women in the access to, and supply of, goods and services), anti-discrimination has come to be

\footnotetext{
${ }^{3}$ This is why the European Commission's slogan, i.e. "justice for growth", sounds paradoxical. See: The EU Justice Agenda for 2020: Strengthening Trust, Mobility and Growth within the Union (Strasbourg, 11.3.2014 COM(2014) 144 final. Cf. Hesselink, 2015, pp. 9-10).
} 
considered as the general principle of the EU law and as a unique European achievement (cf. Somek, 2011). However, it is frequently claimed that anti-discrimination provisions of the EU law endanger the principle of freedom of contract or even the whole marketbased economy of the European Union (cf. Basedow, 2008).

Consumer protection. Alongside the anti-discrimination law, a high level of consumer protection is a crucial feature of the EU private and contract law. Consumers, rightly considered to be weaker parties when it comes to dealings with professionals, are protected in a variety of ways and at different stages of contractual dealings. Some terms in consumer contracts are entirely forbidden as they are considered unfair (Directive 93/13/EEC on unfair terms in consumer contracts) or commercial practices (Directive 2005/29/EC concerning unfair business-to-consumer commercial practices in the internal market). European consumers enjoy certain informational rights with regard to the products they buy (pre-contractual information duties of the professionals) as well as certain withdrawal rights. ${ }^{4}$ All of these measures are highly regulatory, which amounts to limiting freedom of contract of both consumers and professionals in a variety of ways.

Access justice. The concept of access justice has been introduced by Hans Micklitz; it is supposed to be a form of justice specific to the EU, closely related to its particular features, and distinct from both corrective and distributive justice. In the author's own words:

Access justice materializes the theoretical chance of EU citizens to participate in the market so as to make is a realistic opportunity. Access justice lays down procedural requirements for proper law enforcement of EU private law. Access justice provides for an institutional design that allows for the participation of EU citizens in civil society. Access justice distributes and redistributes opportunities. Therefore, access justice should be understood as a thin version of social distributive justice. (Micklitz, 2018, pp. 1-2)

The exact relationship between the concepts of access justice and corrective justice is a very interesting subject, although it cannot be pursued here. For the purposes of this article, it is sufficient to notice that the concept of access justice highlights the continuity of contract law, where "access to the contract, the substance of the contract and the termination of the contract" (Micklitz 2018, p. 217) are different stages of the 'contract life', each of which may be abused in a number of ways. This corresponds to various forms of consumer protection at different stages of contractual dealings and is quite significant for my attempt to adjust the corrective justice theory of contract law to the EU legal reality, to which I will now turn.

\section{4.}

I shall start with the strong corrective justice theory. It seems clear that all of the above features of the European contract law are inconsistent with the bipolar relationship be-

\footnotetext{
${ }^{4}$ See e.g. art. 6.1. of Directive 2002/65/EC concerning the distance marketing of consumer financial services and amending Council Directive 90/619/EEC as well as Directives 97/7/EC and 98/27/EC: "The Member States shall ensure that the consumer shall have a period of 14 calendar days to withdraw from the contract without penalty and without giving any reason."
} 
tween contractual parties and, therefore, with the principle of corrective justice as understood by Weinrib. Within such a framework, it is indeed impossible to consider the European Regulatory Private Law as private law at large. Hence, a proponent of the strong corrective justice theory of contract has to face the dilemma stated at the very beginning of the article. On the one hand, they can (i) call for a significant modification or even abandonment of the EU contract law as inconsistent with the principle of corrective justice (the only principle that should govern contract law). On the other hand, they can (ii) try to accommodate the ERPL into their conceptual framework by claiming that regulatory provisions of the EU law, although they themselves are not part of contract law, set limits to the domain of freedom of contract and contract law as such. However, both of these options are not particularly satisfactory. The former one seems to be overly revolutionary and incompatible with a great body of doctrinal research on the European private law. The latter one poses a threat of 'explaining away' a significant part of the phenomenon one wants to investigate, and is inconsistent with the intuitive understanding of the ERPL as part of contract law. Therefore, there is only one option (iii) that remains. Namely, the strong corrective justice theory of contract law has to be deemed deficient, since it fails when tested against the background of the European contract law. Since it seems that it cannot be reconciled with such a background without losing its essential characteristics, the strong corrective justice theory should be abandoned.

What about the moderate corrective justice theory? It does not exclude distributive, paternalistic, moralistic, or other instrumental considerations from the domain of contract law a priori. Therefore, it is possible for this theory to accommodate regulative, instrumental, fragmented, experimental, and privatized elements of the European contract law, as well as anti-discriminatory and consumer protection rules of the private law, and the concept of access justice as the form of justice specific to the EU law. It is true that, to a certain extent, all of these features limit the domain of corrective justice and infringe the principle of freedom of contract (in the last part of this article I will elaborate on what the exact nature of such an infringement is and whether it is infringement at all). However, corrective justice and freedom of contract are not the only principles governing private and contract law. People should not be discriminated against because of their gender, ethnicity, religion, or sexual orientation. Consumers should not be fooled by producers. It should be guaranteed that everyone has free and substantial access to the market. These are just some of the principles that can govern private law, alongside principles of corrective justice and freedom of contract. In some cases, impossible to be pointed out in abstracto, the former one can outweigh the latter one. ${ }^{5}$ The question about to what extent the freedom of contract can be

\footnotetext{
${ }^{5}$ The seminal case here is Henningsen v. Bloomfield Motors, famously analyzed by Ronald Dworkin (1981, pp. 23-24). The main issue was whether an automobile manufacturer may contractually limit their liability when the automobile is defective, even if it results in a serious injury of a buyer. The court had to consider two different principles, namely the principle of freedom of contract (which would exclude the manufacturer's liability) and the principle of automobiles' users' safety (which would support the imposing of liability on a manufacturer). Eventually, in the Henningsen case the judges opted for the latter option and imposed liability on Bloomfield Motors; the principle of freedom of contract was outweighed by the principle of automobiles' users' safety.
} 
compromised for the sake of other values and principles remains inevitably ambiguous. That said, there is no doubt that the two can coexist within the domain of private law.

My argument for the modification of corrective justice theory is, therefore, consistent with the moderate theories. The main point is rather simple. I assume that the basic definition of the principle of corrective justice, one mentioned at the beginning of the first part of this article, is correct. Corrective justice is a principle that requires the harm wrongfully suffered by an individual to be repaired (corrected). Next, it is said that such a simple principle, together with monist theories of contract law based on it, cannot grasp the specificity of the regulatory European contract law that is supposed to realize a wide range of public policies. However, as is often the case in both morality and law, the principle of corrective justice is not as simple as it might seem.

The meaning of the concepts crucial to the definition of the principle of corrective justice is very broad. I shall focus on the concept of harm, since its essence partly determines the denotation of the other concepts in question. I have already mentioned that the harm suffered by a party, in the context of private law, can be a result of different events, such as tort, unjust enrichment, or a breach of contract. These are different kinds of harms, which require different kinds of treatment. Therefore, the meaning of the concept of harm can be different in various settings. Apparently, this differentiation goes even further. Within contract law itself there is a variety of contractual types and, consequently, different types of harms that can be suffered and have to be repaired. The harm of a disappointed consumer is different from the harm of a fooled business partner, or the harm of a person that has been denied access to a certain service because of their skin color. This also implies that different harms may be suffered at different stages of contractual, as well as pre-contractual and post-contractual, relationships. The characteristics of contracting parties, an exact type of contract and values it aims to realize, the circumstances of its formation, the conflict-solving body that enforces contractual terms - all of these elements have to be taken into account while evaluating whether a genuine harm has been suffered, whether a party of contract was wronged, and whether their harm has to be repaired (and in what way).

The proposed extension of the meaning of harm is, therefore, threefold. Firstly, it helps to distinguish different branches of private law, since harms suffered as a consequence of tort, a breach of contract, or unjust enrichment are all very different. Secondly, even within the domain of contract law, it helps to distinguish between different types of contracts realizing different values, the breach of which results in different harms. Thirdly, even within one contractual type, different harms can be suffered at different stages, namely at the stage of contract formation, contract interpretation, contract enforcement, and so on.

Such an extension seems to consort with many characteristics of the ERPL. The regulatory and fragmented character of the European contract law, designed to realize a variety of policy goals, means that different values (e.g. consumer protection, anti-discrimination) are protected by different types of contracts. Therefore, different harms result from the malfunctioning of each type. The variety of valuable goals that are protected and possible harms that are suffered makes it inevitable for the EU law to be experimental and, to a 
certain extent, privatized. Accordingly, the "continuity" of "contract life"- the "access to the contract, the substance of the contract and the termination of the contract" (Micklitz, 2018 , p. 217), all highlighted by the concept of access justice, means that a variety of harms is suffered at all stages of contractual interactions. In sum, the proposed extension of the meaning of harm helps to open the concept of corrective justice and, as a consequence, make it more flexible and adoptable to a wider range of phenomena. It transforms the concept of corrective justice into a kind of "relational justice" (cf. Dagan and Dorfman, 2016) and modifies it in such a way that it ceases to be monistic and, instead, becomes a pluralistic theory of contract law. In other words, it makes the corrective justice theory of contract law consistent with the legal reality of the European Union law and, thus, overcomes at least one of its deficiencies.

\section{5.}

Before moving on to the conclusion, I shall tackle one more issue. As has already been mentioned, one of the reasons why the corrective justice theory is appealing is that it embraces the principle of freedom of contract, which is one of the most important freedoms for the contemporary liberal thought. One can wonder whether the above considerations are acceptable from the liberal point of view. After all, freedom of contract is not frequently mentioned in the EU legal acts. ${ }^{6}$ However, I would argue that the European contract law can be defended from the liberal point of view.

There seem to be two possible instances when limiting freedom of contract is permissible from the liberal point of view. The first one, in which limiting one party's freedom of contracting enhances another party's right and freedoms; and the second one, in which limiting a party's freedom of contracting can enhance their own rights and freedoms. The first one is rather uncontroversial and is encompassed by the universal Kantian maxim, which states that the freedom of each individual should be able to co-exist with the freedom of everyone else. In that case, the contract of killing or the contract infringing a third party's intellectual property rights is always unacceptable, since making such a contract would be devastating for the substantial rights and freedoms of others. This becomes clear also when one looks at the legal formulations of the principle of freedom of contract, which state that, for example, the parties executing a contract can arrange for their legal relationship at their discretion so long as the content or purpose of the contract is compliant with the nature of the relationship, the law, or the principles of community life (art. $353^{1}$ of the Polish Civil Code).

\footnotetext{
${ }^{6}$ Sometimes in slightly different terms. Cf. Directive 2005/29/EC: "Member States should accordingly be able to continue to ban commercial practices in their territory, in conformity with Community law, for reasons of taste and decency even where such practices do not limit consumers' freedom of choice". See also the Communication from the Commission to the Council and the European Parliament on the European contract law, which states that: "As a matter of principle, all options should allow contracting parties the freedom they need to conclude the contract terms best suited to their specific needs."
} 
The second way, where limiting party's freedom of contracting can enhance their own rights and freedoms, is much more interesting. Although it can look somewhat inconsistent at first sight, it has been dealt with by many liberal thinkers. It was Dori Kimel (2001, relying on Raz, 1988) who most convincingly claimed that liberalism did not have to be necessarily committed to the rigid (or libertarian) conception of the freedom of contract. Kimel's main point is that personal autonomy-expressed by the freedom of contract, among other things - "is valuable only when exercised in pursuit of the good" (Kimel, 2001, p. 487). If one takes a look at the existing legal systems, there are many cases in which limiting freedom of contract - and keeping it limited - does contribute to the pursuit of the good; a variety of examples can be found in the ERPL provisions.

I shall now focus on some pro-consumer prescriptions that have been mentioned before. Enlisting unfair terms and practices in consumer contracts obviously limits the freedom of contracting not only of professional entrepreneurs, but also of consumers themselves. There is no need to point to any particular forbidden contractual terms here, since the whole idea seems clear enough. However, one can wonder whether including such terms in consumer contracts would make consumers' lives better in any way. I reckon that the answer to this question is negative, which is why limiting consumers' freedom of contract is, in some cases, acceptable from the liberal point of view, since it precludes them from the possibility of choosing 'bad' options, therefore enhancing the overall quality of their lives. Thus, limiting freedom of contract is sometimes permissible, especially if it contributes to the enhancement of other personal rights and freedoms, such as the right to not be exploited by the stronger party of the contract, or the freedom from the necessity to choose out of 'bad' options only. This is why the corrective justice approach to contract law, in the modified and open form that has been proposed above, does not have to be committed to the libertarian conception of the freedom of contract, but is still able to consider this freedom fundamental. Therefore, it can still be deemed liberal.

\section{Conclusion}

I remain hopeful that I have managed to outline how the corrective justice theory of contract law - in its moderate form - can be consistent with the regulatory provisions of the European Regulatory Private Law. The transition from the monistic to the pluralistic understanding of the principle of corrective justice enables one to reconcile the autonomybased theory of contract law and the principle of freedom of contract with distributive considerations - and other policy goals - of many contemporary legal regimes. I find this achievement especially important, since the EU legal order can be regarded as the earliest expression of some more general trends that one can see in the contemporary world, such as the emergence of supranational legal systems, the changing role of the state, or employing more and more public policies into contract law, to name but a few. Therefore, the "experimental legal order" of the EU can very well anticipate how legal orders in general will look like in the future of the globalized world. This is also why it was especially 
important to ground the above considerations on an acceptable political philosophy; the theory of perfectionist liberalism in the form sketched above seems to be such a philosophy. I realize that my remarks remain introductory; by no means have I aspired to develop a comprehensive and fully-fledged theory of the European contract law, let alone contract law in general. Nevertheless, I hope that this article can serve as the first step towards developing such a theory.

\section{References}

Basedow, J. (2008). Freedom of contract in the European Union. European Review of Private Law, 16(901), 901-923.

Comparato, G. (2016). Public policy through private Law: Introduction to a debate on European Regulatory Private Law. European Law Journal, 22(5), 621-626.

Dagan, H. (1999). The distributive foundation of corrective justice. Michigan Law Review, 98(1), $138-166$.

Dagan, H. (2016). Between regulatory and autonomy-based private law. European Law Journal, 22(5), 644-658.

Dagan, H., \& Heller, M. (2017). The Choice Theory of Contracts. Cambridge UK: Cambridge University Press.

Dagan, H., \& Dorfman, A. (2016). Just relationships. Columbia Law Review, 116(6), 1395-1460.

Dworkin, R. (1981). Taking Rights Seriously. Cambridge, MA: Harvard University Press.

Englard, I. (2009). Corrective and Distributive Justice: From Aristotle to Modern Times. Oxford, UK: Oxford University Press.

Gardner, J. (2011). What is tort law for? Part 1: The place of corrective justice. Law and Philosophy, $30(1), 1-50$.

Gardner, J. (2014). What is tort law for? Part 2: The place of distributive justice. In J. Oberdiek (Ed.), Philosophical Foundations of the Law of Torts (pp. 335-353). Oxford, UK: Oxford University Press.

Gardner, J. (2018). From Personal Life to Private Law. Oxford, UK: Oxford University Press.

Hesselink, M. (2015). Contract theory and EU contract law. Centre for the Study of European Contract Law Working Paper Series No. 2015-09.

Kimel, D. (2001). Neutrality, autonomy, and freedom of contract. Oxford Journal of Legal Studies, 21(3), 473-494.

Michales, R., \& Jansen, N. (2006). Private law beyond the state? Europeanization, globalization, privatization. The American Journal of Comparative Law, 54(4), 843-890. 
Micklitz, H. (2009). The visible hand of European Regulatory Private Law: The transformation of European private law from autonomy to functionalism in competition and regulation. Yearbook of European Law, 28(1), 3-59.

Micklitz, H. (2011). Social justice and access justice in private law. EUI working papers, Law 2011/2012, Department of Law.

Micklitz, H. (2017). The constitutional transformation of private law pillars through the CJEU. In H. Collins (Ed.), European Contract Law and the Charter of Fundamental Rights (pp. 49-91). Cambridge, UK: Intersentia.

Micklitz, H. (2018). The Politics of Justice in European Private Law. Cambridge, UK: Cambridge University Press.

Raz, J. (1986). The Morality of Freedom. Oxford, UK: Oxford University Press.

Somek, A. (2011). Engineering Equality: An Essay on European Anti-discrimination Law. Oxford, UK: Oxford University Press.

Weinrib, E. (2012a). The Idea of Private Law. Oxford, UK: Oxford University Press.

Weinrib, E. (2012b). Corrective Justice. Oxford, UK: Oxford University Press. 